\title{
Vielfältige Wege. Regionale und überregionale Migrationen
}

\begin{abstract}
Die Menschen Niederösterreichs, ob am Land, in wachsenden Kleinstädten oder in der Residenzstadt Wien, waren überaus mobil und bewegten sich über kürzere oder längere Distanzen. Sie überschritten dabei administrative, geographische und auch kulturelle Grenzen. Neue Menschen, ob aus anderen Provinzen oder aus anderen Ländern ließen sich in Niederösterreich nieder, wenige verließen die habsburgische Provinz. Viele Wanderungen waren saisonal geprägt und Prozesse der Industrialisierung und Urbanisierung verstärkten die räumliche Mobilität. Unterschiedliche und sehr flexible Migrationsmuster haben im Verlauf des I9. Jahrhunderts wesentlich zum sozialen Leben in Niederösterreich beigetragen.
\end{abstract}

Manifold Paths. Regional and Superregional Migrations. People of Lower Austria, whether living in an urban area, in small towns or in the capital Vienna, moved over shorter and longer distances, crossing administrative, geographic, and cultural borders. New people from other provinces or from other nations settled in Lower Austria, while few left the Habsburg province. Many migrations were characterized by seasonal moves. Processes of industrialization and urbanization intensified spatial mobility. During the nineteenth century, social life in Lower Austria was characterized by various and highly flexible migration patterns.

Keywords: migrations, industrialization, urbanization, population growth

doi.org/10.52035/noil.2021.19jh02.03

Veröffentlicht nach externer Begutachtung (doppelblind) / published after external peer review (double blind) 